\title{
Barriers to using consumer science information in food technology innovations: An exploratory study using Delphi methodology
}

\author{
Marian E. Raley ${ }^{a}$, Maddalena Ragona ${ }^{\mathrm{b}}$, Siet J. Sijtsema ${ }^{\mathrm{c}}$, Arnout R.H. \\ FiSCHER $^{\mathrm{d}}$, AND LYNN J. FREWER ${ }^{\mathrm{a}^{*}}$ \\ ${ }^{\text {a }}$ Food and Society Group, School of Agriculture, Food and Rural Development, Newcastle University, \\ Newcastle upon Tyne NE1 7RU, UK \\ b Dipartimento di Scienze Statistiche, Università di Bologna, Via Belle Arti, 41, 40126 Bologna, Italy \\ ${ }^{\mathrm{c}}$ LEI Wageningen UR, Postbus 35, 6700 AA Wageningen, The Netherlands \\ ${ }^{\mathrm{d}}$ Wageningen UR Marketing and Consumer Behaviour, Hollandseweg 1, $6707 \mathrm{KN}$ Wageningen, The \\ Netherlands \\ ${ }^{*}$ Corresponding author \\ lynn.frewer@newcastle.ac.uk \\ TEL: +44 (0) 1912088272 \\ FAX: +44 (0) 1912085411
}

Received: 27 October 2014; Published online: 18 April 2016

\begin{abstract}
Food technology innovation has the potential to deliver many benefits to society, although some technologies have been problematic in terms of public acceptance. In promoting the commercial success of innovative technological processes and resultant products it will be important to incorporate information relating to consumer preferences and concerns during their development. The barriers to the utilisation of consumer information during technological development was explored using a two round Delphi study involving 75 experts with an interest in new food technology (food technologists and consumer scientists). There was overall agreement that consumer information should be used in technology implementation and product design, and that good communication between key actors at pivotal stages during the development of new food technologies and products was important. However disciplinary differences were perceived to be a barrier to communication, as were difficulties associated with producing consumer information usable by food technologists. A strategy to improve inter-disciplinary communication is proposed, involving the creation of multi-disciplinary teams working together throughout the development project's duration, including those with interdisciplinary experience. Deficiencies in the specification of the information required from consumer scientists need to be overcome. Consumer science results need to be concrete and presented as salient to and usable by food technologists.
\end{abstract}

Keywords: Consumer science; Food technology; Communication; Innovation; Delphi; Interdisciplinary

\section{Introduction}

Food technology can deliver many benefits, from improved food safety and food risk mitigation

Copyright (C)2016 ISEKI-Food Association (IFA) (e.g. see, inter alia, Rendueles et al., 2011; Uzogara, 2000) and improved nutrition (e.g. see, inter alia, Mussatto \& Mancilha, 2007; Gibson, Probert, Van Loo, Rastall, \& Roberfroid, 2004), 
to increased food sustainability (e.g. see, inter alia, Tilman, Balzer, Hill, \& Befort, 2011; Toepfl, Mathys, Heinz, \& Knorr, 2006), and improved food security (FAO, 1996). Technological innovation in food production may involve the application of emerging enabling technologies that are associated with societal disquiet such as genetic modification (GM) (see, inter alia, Costa-Font, Gil, and Traill (2008), Gaskell et al. (2004), Frewer et al. (2013)), nanotechnology (Gupta, Fischer, \& Frewer, 2012; Macoubrie, 2004; Macnaghten, 2014; Siegrist, Keller, Kastenholz, Frey, \& Wiek, 2007), or synthetic biology (Torgersen, 2009). In order to succeed in a highly competitive market, consumers must value novel products in order to accept and consume them (Stewart-Knox \& Mitchell, 2003). A high level of innovation failure in the food industry has been noted (Costa \& Jongen, 2006). Some technologies applied to innovative food production processes have proven problematic in terms of public acceptance (David \& Thompson, 2011).

Historically, research into the determinants of public acceptance of emerging food technologies has occurred subsequent to public rejection of a particular application. Examples include the research examining consumer acceptance and rejection of GM foods (e.g. Costa-Font et al., 2008; Gaskell et al., 2004), food irradiation (e.g. Henson, 1995; Schutz, Bruhn, \& Diazknauf, 1989) and food additives (Shim et al., 2011). To ensure novel food products align with consumer expectations, identification of those features of new technologies which are likely to be problematic in terms of public acceptance is needed, together with information about which products are likely be favoured by (some) consumers. There is an extensive consumer science literature which can deliver understanding of what and how consumer priorities and preferences are developed (e.g. Bettman, Luce, \& Payne, 1998; Thompson, 1997), and why public rejection of technologies may occur (e.g. Kleijnen, Lee, \& Wetzels, 2009; Frewer, Bergmann, et al., 2011). However, for this information to be incorporated into product design at an early stage of the innovation trajectory, interdisciplinary collaboration between food technologists (who typically have a life sciences or engineering background) and con- sumer scientists (frequently conducting research through application of social science theories and methodologies) is needed. Incorporating consumer information in the early stages of new product development processes has often been ignored or poorly executed (Ronteltap, van Trijp, Renes, \& Frewer, 2007; van Kleef, van Trijp, \& Luning, 2005). Internal communication processes are an under-researched area with much existing research focusing on Asia, and frequently associated with small 'incremental' innovations rather than highly innovative changes (Jacobsen et al., 2014).

The 'innovation' referred to in this paper does not directly relate to 'break-though' research (for example, the development of novel technologies) but rather how these technologies are applied to the agrifood sector. For example, there is considerable evidence to suggest that emerging technologies such as genetic modification, nanotechnology or synthetic biology are (largely) acceptable to the public, but that when these are applied within a specific sector the risks perceived by the public must be outweighed by the associated benefits of their application (Frewer et al., 2014). However, the results of the research may equally apply to other forms of product innovation where consumer acceptance is required, but which do not necessarily involve the application of emerging technologies, in order to 'finetune' new food innovations in alignment with consumer expectations.

The research reported here was conducted as part of EU Framework Programme 7 project Connect4Action which focuses on improving communication between key actors during the food technology development process. The main goal of the research was to identify barriers to, and facilitators of, inclusion of consumer science research in food product development. The research aimed to elicit stakeholder opinion regarding effective sharing and incorporation of consumer information during the application of new food technologies, in order to inform the development of practical guidelines to improve internal communication in institutions with interests in food technology.

The specific research questions were:

- When are the critical points for inclusion of 
consumer information in product design?

- What are the barriers which impede the incorporation of consumer information into food product design?

- How can the incorporation of consumer information into food product design be improved?

\section{Methods}

\subsection{Methodological issues}

A two-round Delphi study was selected as an appropriate method for eliciting expert opinions (Linstone, Turoff, et al., 1975; Turoff, 1970). Delphi involves iterated questionnaires being presented to anonymised groups of experts or stakeholders in a series of rounds to produce a 'group judgement'. Variations of the method exist, such as the number of rounds of questionnaires used, whether the first round is structured (quantitative) or unstructured (qualitative), and whether the process takes place 'online' (Gordon \& Pease, 2006). For this study, focused on integrating research within scientific communities currently working 'in parallel', and potentially geographically located throughout Europe, the Delphi method offers several advantages over other approaches. It avoids the difficulty of gathering stakeholder groups together as required for workshops (Walls, Rowe, \& Frewer, 2011) and overcomes the linguistic constraints which may apply in workshops to experts who are less fluent in the selected workshop language. Except for the first round, each questionnaire provides anonymised feedback from the previous round's responses. By sharing individual views anonymously, potential social and political interactions that take place within groups, which can prove counterproductive for identifying acceptable problem solutions, may be ameliorated.

\subsection{Survey structure and design}

\section{Round 1 Delphi questionnaire}

The first round Delphi questionnaire sought to identify the barriers which prevent the incorpora- tion of information about consumer preferences during the development of new food technologies and derived products. The selection of topics built on the existing literature in the area together with the expertise of researchers and experts involved in the project. The inclusion of a preparatory workshop is frequently useful in the development of the first round questionnaire (Frewer, Fischer, et al., 2011). An interactive workshop, comprising of researchers working on the project and invited experts, was held in The Hague, Netherlands in January 2012. The workshop was attended by a broad group which included natural and social scientists interested in new food technology, working in academia /research institutes, non-governmental organisations (NGOs) or industry. Due to its small scale and geographical location the workshop did not necessarily reflect the broader constituency of interested stakeholders.

A draft survey was developed and piloted by 2 individuals with profiles similar to the target participant group, and a final version was developed after further piloting. The final Round 1 survey contained 14 closed questions answered using a three point scale (either 'Yes' /'No' /'No opinion' or 'Agree'/ 'Disagree'/ 'No opinion'), each followed by an open question which allowed participants to explain or elaborate upon their answer. Open question responses allowed further analysis of participant opinions, and identified issues for use in Round 2 as feedback and/or as the basis of further questions. Eight questions elicited personal information (such as age, experience and disciplinary interest).

\section{Round 2 Delphi questionnaire}

The Round 2 questionnaire contained themed groups of quantitative questions which aimed to gain deeper understanding of issues arising from Round 1, and introduce issues raised by individuals to all survey participants. Questions were preceded by controlled feedback which reported the level of agreement/ disagreement with Round 1 questions, accompanied by selected quotations which illustrated the main arguments given by participants to explain their responses. All Round 2 questions were answered using fivepoint Likert-like scales, anchored at either $1=$

\begin{tabular}{l|l|l|l} 
IJFS & April 2016 | Volume 5 & pages 39-53
\end{tabular} 
'Strongly disagree' and 5= 'Strongly agree' or at $1=$ 'Very unimportant' and $5=$ 'Very important'. Both scales included the category $3=$ 'Neither agree or disagree' (or 'Neither important or unimportant'). A further 'Don't know' option was provided, and respondents were invited to comment on their responses. Copies of the questionnaires are available from the corresponding author.

\section{Participants}

The study utilised a database of potential participants developed as part of the Connect4Action project consisting of individuals with interests in food technology and/or consumer science, and food innovation processes, primarily but not exclusively drawn from all areas of Europe, from a range of relevant stakeholder and end-user constituencies, including the food industry, academia and other research establishments, primary producers, NGOs and regulation/government.

\section{Survey administration}

The first questionnaire was administered in September 2012 with a 3 week deadline for completion. A reminder was sent after 2 weeks, and a final contact was made to extend the deadline by a further 2 weeks. The second questionnaire was administered in January 2013 with a 3 week deadline for completion, and a reminder was sent after 2 weeks. Both questionnaires were primarily administered on-line, but the questionnaire was also made available in English and Italian as a text document for completion off-line. Respondents had the option of completing the questionnaire in English, Spanish, Italian or Portuguese.

\subsection{Sample characteristics}

A total of 356 individuals were contacted with the Round 1 questionnaire from whom 75 usable responses were received, corresponding to a response rate of $21 \%$. Of these, approximately $72 \%$ responded to the second round questionnaire (see Table 1). This rate of attrition between rounds is typical of Delphi studies in- volving expert or professional stakeholder groups (e.g. Wentholt, Rowe, Koenig, Marvin, and Frewer (2009). Round 1 participants were almost evenly split between consumer scientists and food technologists (28\% and $32 \%$ respectively). A further $15 \%$ (referred to as 'Dual qualified') indicated they had interests in both food technology and consumer science. The final $25 \%$ were classified as 'other stakeholders'. In all, $73 \%$ were resident in the EU (Austria, Belgium, Finland, France, Germany, Greece, Hungary, Italy, Netherlands, Poland, Portugal, Romania, Slovenia, Spain, UK), $23 \%$ in non-member states in Europe and $4 \%$ outside Europe. The mean age of respondents was 45 years (minimum 25; maximum 65) and the mean years of experience was 18 (minimum 3; maximum 40). Overall $68 \%$ of Round 1 respondents reported experience in developing new food products. The proportion of consumer scientists with such experience was comparatively small at $52 \%$ (11 out of 21 ) compared to food technologists (23 of 24) and 'Dual qualified' (11/11).

\section{Results}

\subsection{Delphi study, Round 1 results}

Qualitative responses were coded, and all closed choice (quantitative) questions divided into those where general agreement of opinion arose (Table 2) or not (Table 3). General agreement was defined as occurring when more than $70 \%$ of the participants agreed with a particular issue (see Frewer, Fischer, et al. (2011). Participants agreed that external communication (between businesses and end-users) and internal communication (between key actors involved in new product development) is important during the process of food technology development if commercial failure is to be avoided. Responses to open questions emphasised the need to communicate consumer information between actors:

- 'We should know and understand the wishes of consumers. Therefore the communication between actors is very important.' (Turkey, food technologist) 
Incorporating consumer science information during food technology development $\mid 43$

Table 1: Response to the $1^{\text {st }}$ and $2^{\text {nd }}$ rounds of the Delphi questionnaire

\begin{tabular}{|c|c|c|c|c|}
\hline Participant characteristics & Classification & $\begin{array}{c}\text { Round } 1 \\
\text { participants } \\
n=\end{array}$ & $\begin{array}{c}\text { Round } 2 \\
\text { participants } \\
n=\end{array}$ & $\begin{array}{c}\text { Response rate, } \\
\text { Round } 2 \\
\text { (as \% of round 1) }\end{array}$ \\
\hline \multirow{4}{*}{ Interest } & \multirow{4}{*}{$\begin{array}{l}\text { Consumer/social scientist } \\
\text { Food technology } \\
\text { 'Dual qualified' (Consumer } \\
\text { Science and Food Technology) } \\
\text { Other }\end{array}$} & 21 & 9 & 42.9 \\
\hline & & 24 & 22 & 91.7 \\
\hline & & 11 & 8 & 72.7 \\
\hline & & 19 & 15 & 78.9 \\
\hline \multirow{7}{*}{ Sector } & Primary production & 3 & 2 & 66.7 \\
\hline & Food industry & 14 & 11 & 78.6 \\
\hline & Academia/research centres & 44 & 31 & 70.5 \\
\hline & Regulation/government & 6 & 4 & 66.7 \\
\hline & NGOs & 1 & 1 & 100.0 \\
\hline & Other & 5 & 4 & 80.0 \\
\hline & Missing & 2 & 1 & 50.0 \\
\hline \multirow{2}{*}{$\begin{array}{l}\text { Professional experience of new } \\
\text { food product development }\end{array}$} & Experienced & 51 & 39 & 76.5 \\
\hline & Not-experienced & 24 & 15 & 62.5 \\
\hline \multirow{2}{*}{ Gender } & Male & 41 & 29 & 70.7 \\
\hline & Female & 34 & 25 & 73.5 \\
\hline \multirow{4}{*}{ Residence } & Central/Eastern Europe & 13 & 10 & 76.9 \\
\hline & Northern Europe & 30 & 21 & 70.0 \\
\hline & Southern Europe & 29 & 20 & 69.0 \\
\hline & Rest of the World & 3 & 3 & 100.0 \\
\hline \multicolumn{2}{|l|}{ Total respondents } & 75 & 54 & 72.0 \\
\hline
\end{tabular}

- Simple mistakes can be avoided at an early stage. Improvements can be included during development and before production has been started.' (Austria, consumer scientist)

Participants agreed that problems exist relating to disciplinary differences, the adequacy of consumer research methods, and poor communication between food chain actors.

A number of questions did not result in participant agreement (Table 3). These were mainly related to the transfer of data between consumer science and technology development and vice versa. 'No opinion' was commonly the most frequent response, indicating uncertainty regarding what happens to consumer science information after it has been gathered, even within the group with experience in new food product development.

\subsection{Delphi study, Round 2 results}

Tables 4 to 8 display results from Round 2 and show the weighted average for the whole sample. The weighted average corrects for the uneven sizes of 4 groups within the sample (consumer scientists, food technologists, dual qualified and 'other') to prevent bias towards the numerically largest group. Results for consumer scientists and food technologists are shown separately to highlight differences in responses.

\section{Critical points for inclusion of consumer information in product design}

Table 4 summarises results from a series of questions focused on participants' opinions regarding the stages in the product development cycle where consumer information is most relevant. A 
Table 2: Round 1 questions with consensus or 'majority' agreement by participants

\begin{tabular}{lc}
\hline Issue & \% agree \\
\hline $\begin{array}{l}\text { Development of new food technologies is important to enhance European } \\
\text { competitiveness in the agri-food sector }\end{array}$ & 97.3 \\
\hline $\begin{array}{l}\text { Communication with end users/consumers about new food technologies is } \\
\text { critical to consumer acceptance }\end{array}$ & 94.4 \\
\hline $\begin{array}{l}\text { It is important to take account of consumer preferences when developing } \\
\text { new food products }\end{array}$ & 93.2 \\
\hline $\begin{array}{l}\text { Communication between key actors (food technologists, consumer scientists, } \\
\text { consumers, policy makers, etc.) along the process of food technology }\end{array}$ & 91.7 \\
development is important to avoid commercial failure & 76.7 \\
\hline $\begin{array}{l}\text { Successful food technology development needs more effective consumer } \\
\text { research methods to gather information about consumer preferences. }\end{array}$ & 70.8 \\
\hline $\begin{array}{l}\text { Disciplinary differences represent an important barrier to communication } \\
\text { between food technologists and consumer scientists }\end{array}$ & 64.4 \\
\hline $\begin{array}{l}\text { There is poor communication between different food chain actors when } \\
\text { developing food technologies. }\end{array}$ & 63.4 \\
\hline $\begin{array}{l}\text { Is able to identify a communication problem between key actors which may } \\
\text { determine the failure of new food technologies }\end{array}$ & 63.4 \\
\hline $\begin{array}{l}\text { The development of food technologies is driven more by technological } \\
\text { advances than by consumer preferences and needs }\end{array}$
\end{tabular}

Table 3: Round 1, areas where disagreement occurred

\begin{tabular}{|c|c|c|c|}
\hline \multirow[b]{2}{*}{ Issue } & \multicolumn{3}{|c|}{ Participant responses } \\
\hline & Agree $\%$ & Disagree $\%$ & No opinion $\%$ \\
\hline $\begin{array}{l}\text { Information about consumer requirements, priorities and needs } \\
\text { are not communicated effectively to food technology developers. }\end{array}$ & 33.8 & 17.6 & 48.6 \\
\hline $\begin{array}{l}\text { New consumer research findings often reach food technology } \\
\text { developers too late to be of any use }\end{array}$ & 27.0 & 23.0 & 50.0 \\
\hline $\begin{array}{l}\text { Consumer scientists do not make an effective use of information } \\
\text { on food technology development in their research. }\end{array}$ & 25.7 & 18.9 & 55.4 \\
\hline $\begin{array}{l}\text { Consumer scientists do not interpret research about consumer } \\
\text { priorities and preferences in a way that would be actionable and } \\
\text { salient to new technology development. }\end{array}$ & 27.0 & 24.3 & 48.6 \\
\hline $\begin{array}{l}\text { The food technology development process is too slow in responding } \\
\text { to changes in consumer needs and concerns }\end{array}$ & 25.0 & 40.3 & 34.7 \\
\hline
\end{tabular}


Table 4: Importance/unimportance of incorporating information about consumer preferences at each stage of new process and product development

\begin{tabular}{|c|c|c|c|c|c|c|}
\hline \multirow[b]{2}{*}{ Development stage } & \multicolumn{2}{|c|}{$\begin{array}{c}\text { All }^{a} \\
\text { Percentage } \\
\text { import }\end{array}$} & $\begin{array}{l}\text { Food } \\
\text { f partic } \\
\text { at or u } \\
\end{array}$ & $\begin{array}{l}\text { nologists } \\
\text { its in stak } \\
\text { ortant at }\end{array}$ & $\begin{array}{l}\text { Cons } \\
\text { holder } \\
\text { levelop } \\
\end{array}$ & $\begin{array}{l}\text { scientists } \\
\text { indicating } \\
\text { stage }^{b} \\
\end{array}$ \\
\hline & 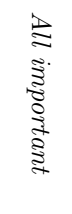 & 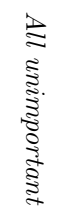 & 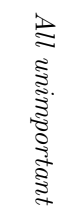 & 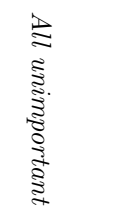 & 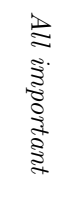 & 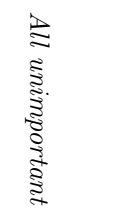 \\
\hline Before starting work on developing the new technological process & 68.7 & 25.7 & 86.4 & 4.5 & 66.7 & 33.3 \\
\hline During development of the new technological process & 57.8 & 13.9 & 59.1 & 9.1 & 44.4 & 33.3 \\
\hline Before starting to develop the new product & 95.6 & 0.0 & 100.0 & 0.0 & 88.9 & 0.0 \\
\hline Early in the product development process & 82.3 & 5.9 & 72.7 & 4.5 & 88.9 & 0.0 \\
\hline Late in the product development process & 62.3 & 18.2 & 45.5 & 18.2 & 55.6 & 22.2 \\
\hline Before marketing activity starts & 88.1 & 9.6 & 90.9 & 0.0 & 100.0 & 0.0 \\
\hline $\begin{array}{l}\text { After the first generation of products has entered the market } \\
\text { (assuming modifications can be made at this stage). }\end{array}$ & 92.5 & 3.4 & 95.5 & 0.0 & 87.5 & 0.0 \\
\hline
\end{tabular}

For clarity of display the responses 'Very important' and 'Important' have been combined into 'All important', and 'Very unimportant' and 'Unimportant' into 'All unimportant'.

${ }^{a}$ weighted to adjust for non-equal sample sizes.

$b$ 'Neither important or unimportant' and 'Don't know' responses used in percentage calculations but not displayed.

distinction was made between the development of new food technologies (or processes) which referred to the generation and development of underlying scientific processes, and the development of new food products which referred to the development of food products which utilise new technology.

Information about consumer preferences was considered useful throughout the development process, and seemed most relevant when considering translation of enabling technologies to specific products, especially at the stages when critical decisions are made prior to product development and marketing activities, and in response to feedback following product launch. Interestingly, the food technologists attached greater importance to consumer science information in the earliest stages of technological development compared to consumer scientists. Public engagement with early developments in technological trajectories may be essential so that due consideration may be given to societal concerns and priorities.

\section{Barriers to using consumer science information}

Failure to incorporate information concerning consumer preferences and requirements into product design means consumers may reject new products. In Round 2 of the Delphi, respondents were asked to indicate the extent to which they agreed or disagreed with potential reasons, based on open responses in round 1 , which explain why it is difficult for food technology developers to act upon information produced by consumer / social scientists (Table 5). Again a number of 'Neither agree or disagree' responses were received, as indicated by row totals of less than $100 \%$.

The Round 2 results did not show a consensus, but showed differences in the responses of food technologists and consumer scientists. In summary, the food technologists perceived consumer science information as lacking specificity and difficult to apply whereas consumer scientists indicated that food technologists are unable to understand consumer science information and its significance. Substantial disagreement to some questions existed within both the consumer scientists and food technologist groups, suggesting variability in participants' individual experi-

\begin{tabular}{l|l|l|l} 
IJFS & April 2016 & Volume 5 & pages 39-53
\end{tabular} 
ences.

Consumer science research will be valued by food technology and product developing communities only if it utilises robust methodologies, and if the results can be translated into concrete and actionable outcomes in the context of food technology. In round 1 of the Delphi, $76 \%$ of respondents agreed that more effective consumer research methods are needed to determine consumer preferences. In Round 2, respondents were asked to indicate to what extent they agreed or disagreed with a set of statements developed from the open comments from Round 1 (Table 6). There was consensus that, in designing studies, consumer scientists need knowledge and understanding of the technology being developed. Half of both groups indicated that consumer scientists did not have the information they needed to design good studies due to poor specification of the task and a deficit in available information about risk and uncertainty. Improved communication between the 2 disciplines including engaging both consumer scientists and food technologists in the design and interpretation of consumer science research is indicated.

\section{Improving the incorporation of consumer information into food product design}

According to the first round of the Delphi, communication between food technologists and consumer scientists is sometimes ineffective (see Table 2). In round 2, participants were asked whether various measures, identified from open responses in round 1, would improve interdisciplinary communication. Table 7 shows a high level of agreement for most proposed measures. These revolved round establishing an inter-disciplinary team which includes individuals possessing a good understanding of more than one disciplinary area. Formal management interventions to facilitate communication received less approval, and food technologists gave less approval than consumer scientists to allocating budgetary resources to the issue.

The specific activities by which these measures would be implemented during development projects showed a consensus that direct communication between individuals throughout the project life, through meetings and joint working, is important (Table 8). Again there was weaker support for including 'interpreters', yet strong support for embedding inter-disciplinary knowledge by including individuals who are experienced in cross-disciplinary working.

\section{Discussion}

Study participants agreed that interactive communication between key actors (food technologists, consumer scientists, policy makers and other important actors) during the process of food technology development is important if commercial failure is to be avoided. In particular, the need to consider consumer preferences and priorities early was identified as a priority. Consumer scientists perceive the difficulty that food technologists have in understanding and interpreting relevant consumer information as a barrier to effective communication between the disciplines, whereas food technologists perceive 'imprecise reporting' by consumer scientists as an impediment.

There is a need to improve communication between consumer scientists and food technologists, as this will lead to better coordination of work activities and release synergies between the disciplines. This might be achieved through, for example, face-to-face and collaborative meetings within institutions and across research communities. The creation of multidisciplinary teams who work together throughout the entire process of novel product development would increase communication. Interdisciplinary teams could be constructed to include a mixture of researchers with mono-disciplinary skills and interdisciplinary experience (see Fischer, de Jong, de Jonge, Frewer, and Nauta (2005)), and/or a working knowledge of both food technology and consumer science. Such measures may not be practical in smaller companies, where the skills base is less extensive, and there is a need to develop structures to broker partnerships between organisations with the relevant expertise, assuming appropriate mechanisms for intellectual property are put into place. In addition, 
Incorporating consumer science information during food technology development $\mid 47$

Table 5: Agreement or disagreement with the reasons provided regarding why consumer science information is not used by food technologists in food product development

\begin{tabular}{|c|c|c|c|c|c|c|}
\hline \multirow[b]{3}{*}{ Reasons } & \multicolumn{2}{|c|}{$\mathrm{All}^{a}$} & \multicolumn{2}{|c|}{ Food Technologists } & \multicolumn{2}{|c|}{ Consumer scientists } \\
\hline & \multicolumn{6}{|c|}{$\begin{array}{l}\text { Percentage of participants in stakeholder } \\
\text { group indicating agreement or disagreement }\end{array}$} \\
\hline & 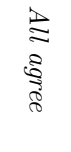 & 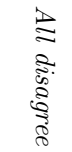 & 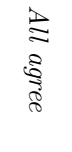 & 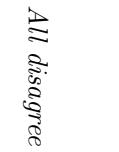 & 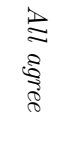 & 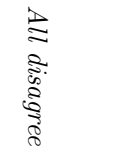 \\
\hline $\begin{array}{l}\text { Information from consumer scientists is not specific enough to the } \\
\text { actual product or process being developed. }\end{array}$ & 57.6 & 12.9 & 63.6 & 4.5 & 44.4 & 22.2 \\
\hline $\begin{array}{l}\text { Information from consumer scientists is not concrete enough for } \\
\text { product and process developers to use in decision making. }\end{array}$ & 55.4 & 20.8 & 54.5 & 18.2 & 44.4 & 33.3 \\
\hline $\begin{array}{l}\text { It takes too long for consumer scientists to report their findings } \\
\text { to food technology developers. }\end{array}$ & 45.3 & 12.2 & 47.6 & 14.3 & 44.4 & 22.2 \\
\hline $\begin{array}{l}\text { Interpretation of the significance of information from consumer } \\
\text { scientists is difficult for food technologists. }\end{array}$ & 60.8 & 24.2 & 45.5 & 27.3 & 66.7 & 22.2 \\
\hline $\begin{array}{l}\text { Food technologists do not share the language or terminology } \\
\text { used by consumer scientists. }\end{array}$ & 56.3 & 12.8 & 54.5 & 13.6 & 66.7 & 0.0 \\
\hline $\begin{array}{l}\text { Food technology developers have no experience in or where } \\
\text { and when to obtain consumer science information. }\end{array}$ & 40.2 & 23.4 & 45.5 & 22.7 & 44.4 & 0.0 \\
\hline $\begin{array}{l}\text { Food technology developers do not know how to apply } \\
\text { consumer science information. }\end{array}$ & 44.6 & 25.5 & 45.5 & 31.8 & 55.6 & 0.0 \\
\hline
\end{tabular}

Responses have been combined: 'Strongly agree' and 'Agree' have been combined into 'All agree', and 'Strongly disagree' and 'Disagree' into 'All disagree'.

${ }^{a}$ weighted to adjust for non-equal sample sizes.

$b$ 'Neither important or unimportant' and 'Don't know' responses used in percentage calculations but not displayed.

Table 6: Agreement or disagreement with the reasons provided regarding what can be done to improve methodologies used in consumer science relevant to food technology developers

\begin{tabular}{|c|c|c|c|c|c|c|}
\hline & \multicolumn{2}{|c|}{$\mathrm{All}^{a}$} & \multicolumn{2}{|c|}{ Food Technologists } & \multicolumn{2}{|c|}{ Consumer scientists } \\
\hline & \multicolumn{6}{|c|}{$\begin{array}{l}\text { Percentage of participants in stakeholder } \\
\text { group indicating agreement or disagreement }\end{array}$} \\
\hline & $\gtrsim$ & $\gtrsim$ & 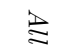 & $\geqq$ & $\geqq$ & $\stackrel{\gtrsim}{\gtrsim}$ \\
\hline & 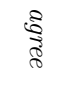 & 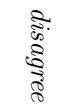 & 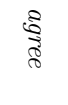 & 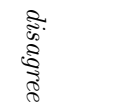 & $\underset{8}{8}$ & 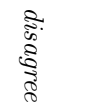 \\
\hline $\begin{array}{l}\text { Consumer scientists need to understand and be able to explain } \\
\text { the pros and cons of the product/process to consumers }\end{array}$ & 88.8 & 1.8 & 95.5 & 0.0 & 87.5 & 0.0 \\
\hline $\begin{array}{l}\text { It is important for consumer scientists to understand how the } \\
\text { technology works. }\end{array}$ & 79.5 & 6.9 & 81.8 & 13.6 & 75.0 & 0.0 \\
\hline $\begin{array}{l}\text { Often there is not enough information available about risk and } \\
\text { uncertainty for consumer scientists to use }\end{array}$ & 56.8 & 9.9 & 50.0 & 18.2 & 62.5 & 0.0 \\
\hline $\begin{array}{l}\text { It is not clear to consumer scientists what information food } \\
\text { technology developers want from them. }\end{array}$ & 54.1 & 8.1 & 50.0 & 13.6 & 50.0 & 12.5 \\
\hline $\begin{array}{l}\text { Consumer scientists need to adopt more effective methods for } \\
\text { gathering information about consumer preferences. }\end{array}$ & 52.6 & 15.0 & 59.1 & 4.5 & 62.5 & 25.0 \\
\hline
\end{tabular}

${ }^{a}$ weighted to adjust for non-equal sample sizes.

$b$ 'Neither agree or disagree' and 'Don't know' responses used in percentage calculations but not displayed.

IJFS | April 2016 | Volume $5 \mid$ pages 39-53 
$48 \mid$ Raley et al.

Table 7: Percentage of stakeholders in each stakeholder group who agreed that possible measures, derived from Round 1 responses, will improve inter-disciplinary communication ${ }^{b}$

\begin{tabular}{lccc}
\hline & All & $\begin{array}{c}\text { Food } \\
\text { technologists } \\
(\mathrm{n}=22) \\
\%\end{array}$ & $\begin{array}{c}\text { Consumer } \\
\text { scientists } \\
(\mathrm{n}=9) \\
\%\end{array}$ \\
\hline $\begin{array}{l}\text { Explicitly recognise interdisciplinary communication as an important } \\
\text { part of food development projects. }\end{array}$ & 97.0 & 100.0 & 87.5 \\
\hline $\begin{array}{l}\text { Establish a multidisciplinary team for the project. } \\
\text { Train multidisciplinary individuals who can contribute to both the } \\
\text { new technology development and consumer science. }\end{array}$ & 100.0 & 100.0 & 100.0 \\
\hline $\begin{array}{l}\text { Allocate part of the project budget specifically to aid communication } \\
\text { between different disciplines and partners. }\end{array}$ & 75.2 & 63.6 & 87.5 \\
\hline $\begin{array}{l}\text { Establish one person with a specific role of managing and } \\
\text { facilitating communication. }\end{array}$ & 59.7 & 63.6 & 50.0 \\
\hline $\begin{array}{l}\text { In the team, include at least one person in the research team who is } \\
\text { able to understand different disciplines. }\end{array}$ & 91.7 & 86.4 & 87.5 \\
\hline
\end{tabular}

${ }^{a}$ weighted to adjust for non-equal sample sizes.

$b$ 'Neither agree or disagree' and 'Don't know' responses used in percentage calculations.

Table 8: Percentage of stakeholders in each stakeholder group who indicated that proposed activities for improving inter-disciplinary communication, derived from Round 1 responses, are important or very important $^{b}$

\begin{tabular}{|c|c|c|c|}
\hline & $\mathrm{All}^{a}$ & $\begin{array}{c}\text { Food } \\
\text { technologists } \\
(\mathrm{n}=22) \\
\%\end{array}$ & $\begin{array}{c}\text { Consumer } \\
\text { scientists } \\
(\mathrm{n}=9) \\
\%\end{array}$ \\
\hline Face-to-face interaction and listening to each other & 100.0 & 100.0 & 100.0 \\
\hline $\begin{array}{l}\text { Reading reports and papers from other disciplines, to become } \\
\text { familiar with their approaches, methods and terminology. }\end{array}$ & 82.3 & 86.4 & 75.0 \\
\hline Individuals working together on elements of the project. & 93.8 & 76.2 & 100.0 \\
\hline $\begin{array}{l}\text { Including 'interpreters' in development projects (i.e. } \\
\text { individuals who understand the methods and vocabulary of } \\
\text { both social science and technology). }\end{array}$ & 76.5 & 77.8 & 71.4 \\
\hline $\begin{array}{l}\text { Recruiting team members with experience of successful } \\
\text { cross-disciplinary work. }\end{array}$ & 90.5 & 86.4 & 85.7 \\
\hline $\begin{array}{l}\text { Interaction between different disciplines throughout the } \\
\text { whole process of development. }\end{array}$ & 95.3 & 100.0 & 87.5 \\
\hline
\end{tabular}

${ }^{a}$ weighted to adjust for non-equal sample sizes.

$b$ 'Neither agree or disagree' and 'Don't know' responses used in percentage calculations.

IJFS | April 2016 | Volume 5 | pages 39-53 
the orientation of food technologists themselves should be taken into consideration as these may result in different attitudes towards cooperation. Some product developers are more technology and cost-oriented, preferring traditional work methods, while others are more customer and consumer-oriented (Sijtsema, Backus, Linnemann, \& Jongen, 2004).

Despite recognition across the stakeholder communities that consumer science information is an important part of food technology implementation and application, the process by which and when it is incorporated into technology implementation and product development is not well defined. A number of barriers to communication were identified, and key recommendations for overcoming them are provided (Figure 1). Future research to test these recommendations in food technology development and application environments is needed.

Given that there is a need to introduce consumer science into the technological innovation process, interdisciplinary courses which incorporate both consumer science and food technology should be more extensively taught within the higher education sector, as well as being included in Continuing Personal Development courses and curricula targeting professionals.

\subsection{Limitations of the research}

The main limitations arise from the size and composition of the stakeholder sample. This reflects a problem encountered in many studies that involve experts, namely the difficulty in communicating with relevant experts and securing their involvement in research. The 75 useable responses obtained to the Delphi round 1 questionnaire was sufficient for exploratory analysis but limited the scope for between-group comparisons. Industry in particular was underrepresented ( $19 \%$ of the sample). Nonetheless, the sample delivered useful insights, as $68 \%$ of round 1 respondents reported experience in developing new food products ( $72 \%$ of round 2 respondents), and $45 \%$ had worked in a food technology team ( $50 \%$ of round 2 respondents). One gap related to the situation as experienced by SMEs, as their participation rates were very low. Despite ef- forts to recruit respondents from this sector, (for example, personal mailings and invitations, and presentations at relevant conferences), their participation did not increase. This may reflect $\mathrm{SME}$ perceptions that the topic is of little relevance, or that the perceived gains from participation are too small to be worthwhile.

Whilst the analysis relied on descriptive statistics, the low response rate and domination of the sample by academic institutions needs to be taken into account when interpreting the data, and represents a limitation of the research.

\subsection{Further research}

A next stage involving 'piloting' the recommendations in a real food technology and product development environment is needed.

The study also highlights a need to encourage low response stakeholder constituencies to participate. Participation involves high levels of involvement in the topic and time commitment, which might explain why low response rates from some constituencies (in particular SMEs and NGOs) were reported. Increasing dissemination of the results (e.g. through academic or professional conference presentations), may facilitate greater willingness to participate in future studies. Continuous emphasis on the relevance of consumer science to improve consumer acceptability of the final product of the food technology process is likely to be highly relevant to potential study participants.

There is clearly a need to explore the issues identified in this research in smaller companies across the European Economic area. It is suggested that a better response rate may be obtained using personal face-to-face interviews, (although given the breadth of activities in the agri-food sector there is a need to sample a broad range of SME stakeholders in each country and across different areas of product innovation), which may be a fruitful topic for research activities in the future.

One way of overcoming barriers between the different disciplines may be through the use of quality function deployment (QFD). QFD is a management tool that 'provides a visual connective process to help teams focus on the needs of the 
customers throughout the total development cycle of a product or process' (Bouchereau \& Rowlands, 2000). Through its application, customer needs are translated into technical requirements for different stages of product development. It has been observed that the application of QFD potentially reduces barriers between different areas of production (Chan \& Wu, 2002). QFD may allow internal organizational communication to transcend barriers. In particular when applied research is being considered, further research into the relevance of QFD in the agrifood sector may be relevant.

\section{Conclusions}

The need to consider consumer preferences and priorities early in the product development process was identified as a priority. Despite recognition that consumer science information is an important part of food technology development, more defined processes regarding incorporation of consumer science information into product development are needed. Education and organizational structuring need to address the issue of cross-disciplinary research if more effective use of consumer science information is to be made.

\section{Acknowledgements}

We would like to thank the European Commission for funding this research through the Framework Program 7 project Connect4Action, Grant Agreement number 289023. We are indebted to everyone who participated in the Delphi study and to project partners for their valuable contributions.

\section{References}

Bettman, J. R., Luce, M. F., \& Payne, J. W. (1998). Constructive consumer choice processes. Journal of Consumer Research, 25(3), 187-217. doi:10.1086/209535

Bouchereau, V. \& Rowlands, H. (2000). Methods and techniques to help quality function deployment (QFD). Benchmarking: An International Journal, 7(1), 8-20. doi:10.1108/ 14635770010314891
Chan, L. K. \& Wu, M. L. (2002). Quality function deployment: a literature review. European Journal of Operational Research, 143(3), 463-497. doi:10 . 1016 / S0377 2217(02)00178-9

Costa, A. I. A. \& Jongen, W. M. F. (2006). New insights into consumer-led food product development. Trends in Food Science 8 Technology, 17(8), 457-465. doi:10.1016/j.tifs. 2006.02.003

Costa-Font, M., Gil, J. M., \& Traill, W. B. (2008). Consumer acceptance, valuation of and attitudes towards genetically modified food: review and implications for food policy. Food Policy, 33(2), 99-111. doi:10. 1016/j.foodpol.2007.07.002

David, K. \& Thompson, P. B. (2011). What can nanotechnology learn from biotechnology?: Social and ethical lessons for nanoscience from the debate over agrifood biotechnology and GMOs. Academic Press.

FAO. (1996). Rome Declaration and World Food Summit Plan of Action. Rome. Retrieved from www.fao.org / docrep / 003 / X8346E/ x8346e02.htm\#P1-10

Fischer, A. R. H., de Jong, A. E. I., de Jonge, R., Frewer, L. J., \& Nauta, M. J. (2005). Improving food safety in the domestic environment: the need for a transdisciplinary approach. Risk Analysis, 25(3), 503-517. doi:10.1111/j.1539-6924.2005.00618.x

Frewer, L. J., Bergmann, K., Brennan, M., Lion, R., Meertens, R., Rowe, G., ... Vereijken, C. (2011). Consumer response to novel agri-food technologies: implications for predicting consumer acceptance of emerging food technologies. Trends in Food Science \& Technology, 22(8), 442-456. doi:10. 1016/j.tifs.2011.05.005

Frewer, L. J., Fischer, A. R. H., Wentholt, M. T. A., Marvin, H. J. P., Ooms, B. W., Coles, D., \& Rowe, G. (2011). The use of Delphi methodology in agrifood policy development: Some lessons learned. Technological Forecasting and Social Change, 78(9, SI), 1514-1525. doi:10 . 1016/ j . techfore.2011.05.005

Frewer, L. J., Gupta, N., George, S., Fischer, A. R. H., Giles, E. L., \& Coles, D. (2014). Consumer attitudes towards nanotechnolo- 


\section{Type of information required}

- Consumer concerns and preferences about technological processes

- Consumer concerns and preferences regarding product design

- Benefits and risks arising from the technology and products

\section{Overcoming communication barriers}

- Consumer science information needs to be 'translated' to provide information which is relevant to product developers

- Interdisciplinary research needs to be institutionally recognised as providing an important contribution to product development

- Resources need to be allocated to interdisciplinary research including equipping practitioners to gain insight into the work of other disciplines.

- Researchers from different disciplines need to meet and discuss relevant issues throughout the development project, and work jointly on aspects of the project where beneficial.

When in product development is communication needed?

- Ensure delivery of consumer science information is provided early enough in the technology development process to influence product design:

- Before starting to develop a new product (but after the implications of an enabling technology have been identified)

- Before marketing activity starts

- After the $1^{\text {st }}$ generation of products has entered the market.

Increasing the relevance of consumer science information when appropriate

- The results of consumer science research must be concrete and presented in such a way as to be incorporated into new technology development and product design

- The outputs provided by consumer scientists need to be precisely specified by food technologists and/or the wider development team.

Figure 1: Key recommendations regarding the inclusion of consumer science information in food technology innovation processes 
gies applied to food production. Trends in Food Science \& Technology, 40(2), 211225. doi:10.1016/j.tifs.2014.06.005

Frewer, L. J., van der Lans, I. A., Fischer, A. R. H., Reinders, M. J., Menozzi, D., Zhang, X., ... Zimmermann, K. L. (2013). Public perceptions of agri-food applications of genetic modification - a systematic review and meta-analysis. Trends in Food Science \& Technology, 30(2), 142152. doi:10.1016/j.tifs.2013.01.003

Gaskell, G., Allum, N., Wagner, W., Kronberger, N., Torgersen, H., Hampel, J., \& Bardes, J. (2004). GM foods and the misperception of risk perception. Risk Analysis, 24 (1), 185194. doi:10.1111/j.0272-4332.2004.00421.x

Gibson, G. R., Probert, H. M., Van Loo, J., Rastall, R. A., \& Roberfroid, M. B. (2004). Dietary modulation of the human colonic microbiota: updating the concept of prebiotics. Nutrition Research Reviews, 17(2), 259-275. doi:10.1079/NRR200479

Gordon, T. \& Pease, A. (2006). RT Delphi: an efficient, 'round-less' almost real time Delphi method. Technological Forecasting and Social Change, 73(4), 321-333.

Gupta, N., Fischer, A. R. H., \& Frewer, L. J. (2012). Socio-psychological determinants of public acceptance of technologies: a review. Public Understanding of Science, 21(7), 782-795. doi:10.1177/0963662510392485

Henson, S. (1995). Demand-side constraints on the introduction of new food technologies - the case of food irradiation. Food Policy, 20(2), 111-127. doi:10.1016/0306-9192(95) 00020-F

Jacobsen, L. F., Grunert, K. G., Sondergaard, H. A., Steenbekkers, B., Dekker, M., \& Lahteenmaki, L. (2014). Improving internal communication between marketing and technology functions for successful new food product development. Trends in Food Science \& Technology, 37(2), 106-114. doi:10.1016/j.tifs.2014.03.005

Kleijnen, M., Lee, N., \& Wetzels, M. (2009). An exploration of consumer resistance to innovation and its antecedents. Journal of Economic Psychology, 30(3), 344-357. doi:10. 1016/j.joep.2009.02.004
Linstone, H. A., Turoff, M. et al. (1975). The Delphi method: Techniques and applications. Addison-Wesley Reading, MA.

Macnaghten, P. (2014). Nanotechnology, risk and public perceptions. In In pursuit of nanoethics (pp. 167-181). Springer.

Macoubrie, J. (2004). Public perceptions about nanotechnology: Risks, benefits and trust. Journal of Nanoparticle Research, 6(4), 395-405.

Mussatto, S. I. \& Mancilha, I. M. (2007). Nondigestible oligosaccharides: a review. Carbohydrate polymers, 68(3), 587-597.

Rendueles, E., Omer, M. K., Alvseike, O., Alonso-Calleja, C., Capita, R., \& Prieto, M. (2011). Microbiological food safety assessment of high hydrostatic pressure processing: a review. LWT-Food Science and Technology, 44(5), 1251-1260. doi:10.1016/ j.lwt.2010.11.001

Ronteltap, A., van Trijp, J. C. M., Renes, R. J., \& Frewer, L. J. (2007). Consumer acceptance of technology-based food innovations: lessons for the future of nutrigenomics. Appetite, 49(1), 1-17. doi:10.1016/ j.appet.2007.02.002

Schutz, H. G., Bruhn, C. M., \& Diazknauf, K. V. (1989). Consumer attitude toward irradiated foods - effects of labeling and benefits information. Food Technology, 43(10), 8086.

Shim, S.-M., Seo, S. H., Lee, Y., Moon, G.-I., Kim, M.-S., \& Park, J.-H. (2011). Consumers' knowledge and safety perceptions of food additives: evaluation on the effectiveness of transmitting information on preservatives. Food Control, 22(7), 10541060. doi:10.1016/j.foodcont.2011.01.001

Siegrist, M., Keller, C., Kastenholz, H., Frey, S., \& Wiek, A. (2007). Laypeople's and experts' perception of nanotechnology hazards. Risk Analysis, 27(1), 59-69. doi:10. 1111/j.1539-6924.2006.00859.x

Sijtsema, S. J., Backus, G. B. C., Linnemann, A. R., \& Jongen, W. M. F. (2004). Consumer orientation of product developers and their product perception compared to that of consumers. Trends in Food Science E) Technology, 15(10), 489-497. doi:10 . $1016 /$ j.tifs.2004.03.004 
Incorporating consumer science information during food technology development $\mid 53$

Stewart-Knox, B. \& Mitchell, P. (2003). What separates the winners from the losers in new food product development? Trends in Food Science 8 Technology, 14(1), 58-64. doi:10.1016/S0924-2244(02)00239-X

Thompson, P. B. (1997). Food biotechnology's challenge to cultural integrity and individual consent. Hastings Center Report, 27(4), 34-38. doi:10.2307/3528777

Tilman, D., Balzer, C., Hill, J., \& Befort, B. L. (2011). Global food demand and the sustainable intensification of agriculture. Proceedings of the National Academy of Sciences of the United States of America, 108(50), 20260-20264. doi:10.1073/pnas . 1116437108

Toepfl, S., Mathys, A., Heinz, V., \& Knorr, D. (2006). Review: potential of high hydrostatic pressure and pulsed electric fields for energy efficient and environmentally friendly food processing. Food Reviews International, 22(4), 405-423. doi:10.1080/ 87559120600865164

Torgersen, H. (2009). Synthetic biology in society: learning from past experience? Systems and synthetic biology, 3(1-4), 9-17.

Turoff, M. (1970). The design of a policy delphi. Technological forecasting and social change, 2(2), 149-171.

Uzogara, S. G. (2000). The impact of genetic modification of human foods in the 21st century: a review. Biotechnology Advances, 18(3), 179-206. doi:10 . 1016 / S0734 9750(00)00033-1

van Kleef, E., van Trijp, H. C. M., \& Luning, P. (2005). Consumer research in the early stages of new product development: a critical review of methods and techniques. Food Quality and Preference, 16(3), 181201. doi:10.1016/j.foodqual.2004.05.012

Walls, J., Rowe, G., \& Frewer, L. (2011). Stakeholder engagement in food risk management: evaluation of an iterated workshop approach. Public Understanding of Science, 20(2), 241-260. doi:10 . 1177/ 0963662509354543

Wentholt, M. T. A., Rowe, G., Koenig, A., Marvin, H. J. P., \& Frewer, L. J. (2009). The views of key stakeholders on an evolving food risk governance framework: Results from a Delphi study. Food Policy, 34(6), 539-548. doi:10.1016/j.foodpol.2009.06.002

IJFS | April 2016 | Volume 5 | pages 39-53 